\title{
A Systematic Review of Antiaging Effects of 23 Traditional Chinese Medicines
}

\author{
Lixin Wang $\mathbb{D},{ }^{1}$ Xu Zuo $\mathbb{D}^{2},{ }^{2}$ Zhuoer Ouyang $\mathbb{D},{ }^{1}$ Ping Qiao $\mathbb{D}^{1},{ }^{1}$ and Fang Wang $\mathbb{D}^{2}$ \\ ${ }^{1}$ Department of Cell Biology, College of Basic Medical Sciences, Jilin University, Changchun 130021, China \\ ${ }^{2}$ Department of Pathogeny Biology, College of Basic Medical Sciences, Jilin University, Changchun 130021, China
}

Correspondence should be addressed to Ping Qiao; qiaoping@jlu.edu.cn and Fang Wang; wf@jlu.edu.cn

Received 3 March 2021; Revised 13 April 2021; Accepted 28 April 2021; Published 17 May 2021

Academic Editor: Wen-Bin Shang

Copyright (c) 2021 Lixin Wang et al. This is an open access article distributed under the Creative Commons Attribution License, which permits unrestricted use, distribution, and reproduction in any medium, provided the original work is properly cited.

Background. Aging is an inevitable stage of body development. At the same time, aging is a major cause of cancer, cardiovascular disease, and neurodegenerative diseases. Chinese herbal medicine is a natural substance that can effectively delay aging and is expected to be developed as antiaging drugs in the future. Aim of the review. This paper reviews the antiaging effects of 23 traditional Chinese herbal medicines or their active components. Materials and methods. We reviewed the literature published in the last five years on Chinese herbal medicines or their active ingredients and their antiaging role obtained through the following databases: PubMed, EMBASE, Scopus, and Web of Science. Results. A total of 2485 papers were found, and 212 papers were screened after removing the duplicates and reading the titles. Twenty-three studies met the requirements of this review and were included. Among these studies, 13 articles used Caenorhabditis elegans as the animal model, and 10 articles used other animal models or cell lines. Conclusion. Chinese herbal medicines or their active components play an antiaging role by regulating genes related to aging through a variety of signaling pathways. Chinese herbal medicines are expected to be developed as antiaging drugs or used in the medical cosmetology industry.

\section{Introduction}

Aging is the degenerative change in the whole function of the organism that occurs with increasing age [1]. Aging is an extremely complex biological process, and its mechanisms involve the theory of genetic mutation, telomere loss, somatic mutation, free radical damage, immune disorder, mitochondrial dysfunction, and autophagy dysfunction [2, 3]. Cardiovascular disease, cancer, cataracts, osteoporosis, high blood pressure, and neurodegenerative diseases, such as Alzheimer's and Parkinson's diseases, are all linked to aging [4-6]. Given the aging population, many countries enter the aging society, which poses a serious threat to th economic development and human life and health. Therefore, the aging mechanism and antiaging drugs should be urgently studied [7].

The life cycle of the body involves a variety of signaling pathways and transcription factors, such as insulin and insulin-like (insulin/IGF-1 signaling [IIS]), dietary restriction (DR), gonad (germline signaling [GR]), and mitochondrial (mitochondrial signaling [mTOR]) signaling pathways [8-10]. These signaling pathways are shown to be conserved, which is a positive boost for the search for life-extending drugs and strategies to improve health $[11,12]$.

Studies have shown that the drug therapy can effectively delay aging and has a positive effect on aging-related diseases. Aspirin and metformin are commonly used synthetic antiaging drugs $[13,14]$, but these drugs also have significant side effects. Aspirin causes antiplatelet aggregation, and long-term use can easily cause bleeding, and patients taking metformin will have diarrhea, nausea, abdominal discomfort, and other adverse reactions $[15,16]$. The discovery and development of antiaging drugs is difficult, and the progress is slow. Thus, finding a safe and effective antiaging drug is challenging. In recent years, Chinese herbal medicine has been considered a safe and effective antiaging drug with a great potential for development [17].

Herb-drug refers to the substance that is used to prevent and treat diseases and has the function of rehabilitation and 
health care under the guidance of Chinese medicine theory. [18]. Traditional Chinese medicine (TCM) is beneficial for chronic diseases [19]. For example, ginger has a significant effect on reducing circulating C-reactive protein (CRP) and tumor necrosis factor-alpha (TNF- $\alpha$ ) levels, which are systemic inflammatory markers associated with an increased risk of cardiovascular disease [20]. Curcumin may ameliorate hyperandrogenemia and hyperglycemia associated with polycystic ovary syndrome [21]. Moreover, recent studies have found that a variety of TCM and their active components can delay aging and prevent age-related diseases [22, 23]. Polysaccharides, monopolysaccharides, or sesquiterpenes in TCM have anti-inflammatory, antitumor, antiviral, acaroid, and sedative effects, which are considered potential sources for the development of new drugs [24,25]. In this paper, the antiaging and antioxidation effects of TCM or their active components are systematically reviewed.

\section{Materials and Methods}

The review was conducted following the Preferred Reporting Items for Systematic Reviews and Meta-Analyses (PRISMA) statement [26].

2.1. Search Strategy. English publications were searched from PubMed, Scopus, Embase, and Web of Science databases. All databases were limited to the Medical Subject Title Index (MESH/DECS) and available until 30 November 2020. Different combinations of the following keywords were used in the search: "traditional Chinese medicine", "herbal medicine", "TCM", "aging", "anti-aging", "senescence" and "traditional medicine". Besides, we looked at the references of all selected articles to find reports that were not found when we searched for articles.

2.2. Study Selection. By reading the titles and abstracts of the articles, the authors excluded the articles that did not meet the criteria of "Chinese medicine or its active ingredients to delay aging." The antiaging effect of the TCM or its active components was studied in vitro and in vivo, and the possible mechanism was discussed. The following types of articles were excluded from consideration in this review: abstracts, editorial/ letter review articles, meta-analyses, conference proceedings, case reports, patents, human studies, and articles published more than five years ago. The third author had the right to decide on any difference of opinion between the two authors.

2.3. Data Extraction. One author summarized the data in the paper, whereas the other examined the data. Caenorhabditis elegans is a classic model for the study of aging. A pair of data obtained from the experiment with C. elegans as a model is separately summarized in Table 1: types of TCM, role form, component analysis methods, main ingredients, dose, life expectancy increased, key genes, and pathways. Table 2 summarizes the experimental data from other animal models or cell lines: types of TCM, role form action forms, animal models or cell lines, induced way, and pathways.
2.4. Methodological Quality Assessment. Optimized checklists were used to assess the risk and quality of bias of in vivo clinical studies [50, 51]. It includes blind administration, blind administration results, average treatment distribution, and other factors.

2.5. Data Analysis. Given the heterogeneity of the study, data were presented in narrative form, and no pooled statistics, sensitivity analysis, meta-analyses were used.

\section{Results and Discussion}

3.1. Search Results. Figure 1 shows the search flowchart [52]. A total of 1737 articles are not duplicates (PubMed: 164, EMBASE: 567, Scopus: 483, Web of Science: 523 ). By reading the titles, we have selected 212 articles related to TCM and antiaging. Finally, through browsing the full text, 23 articles are recorded in this paper. Thirteen articles are based on C. elegans as animal models, and the other ten articles are based on other animals or cells.

3.2. Study Characteristics and Description. This paper presents a systematic review of 20 studies. Thirteen papers have used the classic C. elegans as an animal model to explore the effect of TCM or its main components on delaying aging. The other seven papers have studied the effects of TCM or its active components on silkworm, yeast, ultraviolet- (UV-) induced senescence cells, UV-induced skin senescence mice, and other aging models. A variety of TCM or their active components have evident inhibitory effects on aging. The chemical structure of some of the main components of Chinese medicine is shown in Figure 2. Moreover, 14 articles were from China; two, from India; two, from Germany; two, from Iran; three, from Korea; one, from Japan.

Several methods are reported in the antiaging experiments of TCM or its active components with C. elegans as the model. The longevity experiment is used to explore the effect of TCM on prolonging the lifespan of nematodes. The effects of TCM on the health status of nematodes are evaluated by measuring their body length and observing their body swing rate and locomotion ability. The effects of TCM on C. elegans resistance to stress are evaluated using heat, oxidative, and heavy metal stress tests. The fecundity of C. elegans is evaluated by counting the fecundity of nematodes and the sexual dominance rate of nematodes. The antioxidant capacity of TCM is evaluated by detecting the reactive oxygen species (ROS) and antioxidant enzyme levels in nematodes. The expression levels of various proteins and mRNAs are detected by transcriptome sequencing, Western blot, and Q-PCR. In addition, some articles have studied the effect of TCM on aging-related diseases.

In addition to the classic model of C. elegans to study the antiaging effect of TCM, yeast, silkworm, and other natural aging models are used in many experiments. Other aging models include hair dermal papilla (DP) cells, UV-induced hairless mouse skin aging model, UV-induced $\mathrm{HaCaT}$ cells and human dermal fibroblasts, $\mathrm{H}_{2} \mathrm{O}_{2}$-induced HUVECs aging, and $\mathrm{D}$-galactose-induced aging mice. Methods include cell viability 
TABLE 1: Antiaging research of TCM and its active components with Caenorhabditis elegans as a model.

\begin{tabular}{|c|c|c|c|c|c|c|c|c|}
\hline Types of TCM & Role form & $\begin{array}{c}\text { Component } \\
\text { analysis method }\end{array}$ & Main ingredients & Dose & $\begin{array}{c}\text { Life } \\
\text { expectancy } \\
\text { increased }\end{array}$ & Key genes & Pathways & References \\
\hline Clove & Essential oil & $\begin{array}{c}\text { Gas } \\
\text { chromatography- } \\
\text { mass spectrometry } \\
\text { (GC-MS) }\end{array}$ & $\begin{array}{l}\text { Aryophyllene; } \\
\text { phenol; 2- } \\
\text { methoxyl-3-(2- } \\
\text { propenyl) }\end{array}$ & $1 \mathrm{mg} / \mathrm{ml}$ & $15.3 \%$ & $\begin{array}{c}\text { daf-16; } \\
\text { sod-3; gst- } \\
4 \text {; cep-1 }\end{array}$ & $\begin{array}{l}\text { Antioxidant } \\
\text { pathway; } \\
\text { insulin/IGF-1 } \\
\text { signaling } \\
\text { pathway } \\
\text { (IIS); } \\
\text { apoptosis } \\
\text { pathway }\end{array}$ & {$[27]$} \\
\hline Coix seed & Essential oil & GC-MS & $\begin{array}{l}\text { Linoleic acid; } \\
\text { oleic acid; } \\
\text { palmitic acid } \\
\text { Chlorogenic acid; }\end{array}$ & $1 \mathrm{mg} / \mathrm{ml}$ & $22.79 \%$ & $\begin{array}{c}\text { mev- } 1 \text {; } \\
\text { hsf- } 1 ; \text { daf- } \\
16\end{array}$ & $\begin{array}{l}\text { Antioxidant } \\
\text { pathway }\end{array}$ & {$[28]$} \\
\hline $\begin{array}{l}\text { Lonicera } \\
\text { japonica }\end{array}$ & $\begin{array}{l}\text { Crude } \\
\text { extractions }\end{array}$ & $\begin{array}{c}\text { High performance } \\
\text { liquid } \\
\text { chromatography } \\
\text { (HPLC) }\end{array}$ & $\begin{array}{c}1,5- \\
\text { dicaffeoylquinic } \\
\text { acid; } 1,3- \\
\text { dicaffeoylquinic } \\
\text { acid }\end{array}$ & $\begin{array}{l}500 \mu \mathrm{g} / \\
\mathrm{ml}\end{array}$ & $21.87 \%$ & $\begin{array}{l}\text { mev-1; } \\
\text { hsf-1; daf- } \\
16 ; \text { daf- } 2 \\
\text { sod-3 }\end{array}$ & $\begin{array}{l}\text { Antioxidant } \\
\text { pathway; IIS }\end{array}$ & {$[29]$} \\
\hline $\begin{array}{l}\text { Glycyrrhizae } \\
\text { radix }\end{array}$ & $\begin{array}{l}\text { Crude } \\
\text { extractions }\end{array}$ & $\begin{array}{l}\text { Reverse phase } \\
\text { high-performance } \\
\text { liquid } \\
\text { chromatography } \\
\text { (RP-HPLC) }\end{array}$ & $\begin{array}{c}\text { Liquiritin; } \\
\text { isoliquiritin; } \\
\text { glycyrrhizic acid }\end{array}$ & $\begin{array}{l}0.24 \mathrm{~g} / \\
\mathrm{ml}\end{array}$ & - & $\begin{array}{c}d a f-16 \\
d a f-18 \\
p d k-1\end{array}$ & IIS & {$[30]$} \\
\hline Gengnianchun & $\begin{array}{c}\text { Aqueous } \\
\text { extract }\end{array}$ & - & - & $\begin{array}{c}3.94 \mathrm{mg} / \\
\mathrm{ml}\end{array}$ & $31.3 \%$ & $\begin{array}{c}\text { age- } 1 \text {; daf- } \\
16\end{array}$ & IIS & {$[31]$} \\
\hline $\begin{array}{l}\text { Rehmannia } \\
\text { glutinosa }\end{array}$ & $\begin{array}{c}\text { Neutral } \\
\text { Polysaccharides }\end{array}$ & $\begin{array}{l}\text { UPLC analysis; } \\
\text { FR-IR spectrum }\end{array}$ & $\begin{array}{l}\text { Galactose, } \\
\text { glucose, and } \\
\text { arabinose }\end{array}$ & - & - & $\begin{array}{l}\text { sod-3; daf- } \\
16 \text {; daf-2 }\end{array}$ & $\begin{array}{l}\text { Antioxidant } \\
\text { pathway; IIS }\end{array}$ & {$[32]$} \\
\hline $\begin{array}{l}\text { Lycium } \\
\text { barbarum }\end{array}$ & $\begin{array}{c}\text { Neutral } \\
\text { Polysaccharides }\end{array}$ & $\begin{array}{l}\text { Phenol-sulfuric } \\
\text { acid method; } \\
\text { HPLC-GPC; FR- } \\
\text { IR spectrum; GC- } \\
\text { MS }\end{array}$ & $\begin{array}{l}\text { Mannose, } \\
\text { glucose, and } \\
\text { galactose }\end{array}$ & $\begin{array}{c}300 \mu \mathrm{g} / \\
\mathrm{ml}\end{array}$ & $20.72 \%$ & $\begin{array}{c}\text { daf- } 16 ; \\
\text { daf- } 2 \text {; daf- } \\
\text { 12; sir-2.1 }\end{array}$ & IIS & {$[33]$} \\
\hline $\begin{array}{l}\text { Juniper berry } \\
\text { (Juniperus } \\
\text { communis L.) }\end{array}$ & Essential oil & GC-MS & $\begin{array}{l}\alpha \text {-pinene; } \\
\text { limonene }\end{array}$ & 10 ppm & $18.5 \%$ & $\begin{array}{l}\text { sod-3; gst- } \\
\text { 4: daf-16; } \\
\text { skn-1 }\end{array}$ & $\begin{array}{l}\text { Antioxidant } \\
\text { pathway; IIS }\end{array}$ & {$[34]$} \\
\hline $\begin{array}{l}\text { Zanthoxyllum } \\
\text { aramatum }\end{array}$ & $\begin{array}{l}\text { Natural } \\
\text { flavonol; } \\
\text { tambulin }\end{array}$ & - & - & $50 \mu \mathrm{M}$ & $16.79 \%$ & $\begin{array}{l}\text { sod- } 1 \text {; sod- } \\
\text { 3; stl-2; } \\
\text { daf-16 }\end{array}$ & $\begin{array}{l}\text { Antioxidant } \\
\text { pathway; IIS }\end{array}$ & {$[35]$} \\
\hline $\begin{array}{l}\text { Hibiscus } \\
\text { sabdariffa } \mathrm{L} .\end{array}$ & & - & - & $1 \mathrm{mg} / \mathrm{ml}$ & $24 \%$ & $\begin{array}{c}\text { daf-16; } \\
\text { skn-1 }\end{array}$ & - & {$[36]$} \\
\hline $\begin{array}{l}\text { Polygonum } \\
\text { multiflorum }\end{array}$ & $\begin{array}{l}\text { Aqueous } \\
\text { extract }\end{array}$ & - & - & $\begin{array}{c}1000 \mu \mathrm{g} / \\
\mathrm{ml}\end{array}$ & $18.6 \%$ & $\begin{array}{c}\text { daf-16; } \\
\text { sir-2.1 }\end{array}$ & IIS & {$[37]$} \\
\hline $\begin{array}{l}\text { Ganoderma } \\
\text { lucidum }\end{array}$ & $\begin{array}{l}\text { Aqueous } \\
\text { extract }\end{array}$ & - & - & $\begin{array}{c}7.5 \mathrm{mg} / \\
\mathrm{ml}\end{array}$ & - & $\begin{array}{l}\text { eat }-2 \\
\text { rsks-1 }\end{array}$ & $\begin{array}{l}\text { mTor/s6k } \\
\text { pathway; } \\
\text { dietary } \\
\text { restriction } \\
\text { pathway }\end{array}$ & {$[38]$} \\
\hline $\begin{array}{l}\text { Astragalus } \\
\text { membranaceus }\end{array}$ & $\begin{array}{l}\text { Astragaloside } \\
\text { IV (AS-IV) }\end{array}$ & - & - & - & $27.8 \%$ & $\begin{array}{l}\text { sod-3; sod- } \\
4 ; \text { sod- } 5 \\
\text { daf- } 16\end{array}$ & $\begin{array}{l}\text { Antioxidant } \\
\text { pathway; IIS }\end{array}$ & [39] \\
\hline
\end{tabular}

analysis, Western blot analysis, in situ staining for $\beta$-galactosidase activity, total collagen determination, stress tolerance and antioxidant activity, determination of antioxidant enzyme content, and other methods. Through the previously mentioned experimental methods, the evident antiaging effects of Chinese medicine or its active components are proven.
3.2.1. Effect of TCM or Its Active Component on Prolonging the Life of C. elegans. C. elegans is a multicellular eukaryote that feeds on microorganisms. Nematodes have unique advantages, such as short life cycle, strong reproductive ability, highly homologous genes with mammals $[53,54]$, and easy maintenance in experiments. These advantages have 
TABLE 2: Antiaging research of TCM or its active components based on other animal or cell models.

\begin{tabular}{|c|c|c|c|c|c|}
\hline Types of TCM & Role form & $\begin{array}{l}\text { Animal models or cell } \\
\text { lines }\end{array}$ & Induced way & Pathways & Ref. \\
\hline $\begin{array}{l}\text { Scutellaria baicalensis } \\
\text { Georgi flowers }\end{array}$ & - & Rat & $\begin{array}{l}\text { D-galactose- } \\
\text { induced }\end{array}$ & $\begin{array}{l}\text { Glutamine-glutamate } \\
\text { metabolic pathway }\end{array}$ & {$[40]$} \\
\hline Rhodiola rosea & Aqueous extract & $\begin{array}{c}\text { Silkworm; Bombyx } \\
\text { mori }\end{array}$ & - & IIS & {$[41]$} \\
\hline $\begin{array}{l}\text { Gentiana rigescens } \\
\text { Franch }\end{array}$ & Gentiopicroside (GPS) & Yeast & - & $\begin{array}{c}\text { Mitochondrial autophagy } \\
\text { pathway; antioxidant pathway }\end{array}$ & {$[42]$} \\
\hline $\begin{array}{l}\text { Zanthoxylum } \\
\text { bungeanum Maxim } \\
\text { (Rutaceae) }\end{array}$ & $\begin{array}{c}\text { Aqueous extract, volatile oil } \\
\text { (VOZ), petroleum ether (PEZ), } \\
\text { and methylene chloride }\end{array}$ & Mice & $\begin{array}{l}\text { D-galactose- } \\
\text { induced }\end{array}$ & $\begin{array}{c}\text { PI3K/Akt/Nrf2 signaling } \\
\text { pathway }\end{array}$ & {$[43]$} \\
\hline Nigella sativa & Fixed oil & Mice & $\begin{array}{l}\text { D-galactose- } \\
\text { induced }\end{array}$ & $\begin{array}{l}\text { Antioxidant pathway; } \\
\text { antiapoptotic pathway }\end{array}$ & {$[44]$} \\
\hline Safflower seed & Oil & HaCaT cells and HDF & $\begin{array}{l}\text { Ultraviolet B- } \\
\text { induced }\end{array}$ & - & {$[45]$} \\
\hline Pomegranate & Dried pomegranate juice & Mice & UVB-induced & - & {$[46]$} \\
\hline $\begin{array}{l}\text { Agastache rugosa } \\
\text { Kuntze }\end{array}$ & Hot water extraction & $\mathrm{HaCaT}$ & UVB-induced & - & {$[47]$} \\
\hline Plumbago zeylanica & - & Dermal papilla cells & - & - & {$[48]$} \\
\hline Ginseng & Ginsenoside $\mathrm{Rb} 1$ & $\begin{array}{c}\text { Human umbilical vein } \\
\text { endothelial cells } \\
\text { (HUVEC) }\end{array}$ & $\begin{array}{c}\mathrm{H}_{2} \mathrm{O}_{2-}^{-} \\
\text {induced }\end{array}$ & SIRT signaling & [49] \\
\hline
\end{tabular}

made them different from other animals. As a result, C. elegans has become the classic model of aging research.

The principal compounds in the clove essential oil (CEO) are caryophyllene, phenol, and 2-methoxyl-3-(2-propenyl) [27]. According to the US Food and Drug Administration, CEO is generally recognized as safe for use as food additive (U.S. Code of Federal Regulations, 21CFR184.1257). CEO significantly extends the nematode's lifespan and improves its reproductive capacity and health. CEO exerts its antioxidant activity by inducing the expression of sod-3 and gst4. In addition, $\mathrm{CEO}$ induces the daf-16/Forkhead box $\mathrm{O}$ (FOXO) nuclear transfer and induces germ cell apoptosis in a cep-1 and daf-16-dependent manner.

Coix seed, a TCM with remarkable medical value, is widely planted in China and Japan. The coix seed oil (CSO) has blood lipid-lowering, antioxidation $[55,56]$ and anticancer effects and can delay the aging of nematode worms [28]. Aging is closely related to environmental stress [57], but CSO can enhance nematode resistance to heat stress, oxidative stress, and heavy metal stress. CSO delays the aging of the nematode and enhances its stress resistance by inducing daf-16 and its downstream genes. Linoleic, oleic, palmitic, and stearic acids in CSO play a key role in this process.

Lonicera japonica (LJ) is also known as Japanese honeysuckle [58], and its main component is chlorogenic acid [29]. Studies have shown that $75 \%$ ethanol extract of L. japonica (LJ-E) can prolong the life of nematodes through the insulin/IGF-1 signal transduction, antioxidant, and autophagy pathways. At the same time, LJ-E improves the health status of $C$. elegans, including the increase in the body swing and pharyngeal pumping frequencies, enhancement of resistance to heat and oxidative stress, and reduction in the ROS level in vivo. In addition, LJ-E and its extract can delay the aging of nematode and prevent Alzheimer's disease.

Glycyrrhizae radix (GR) is usually used in combination with other Chinese herbal medicines to treat peptic ulcers, hepatitis C, and skin diseases [59-62]. Recent studies have shown that the long-term exposure to GR can prolong the lifespan of nematodes, enhance their motor capacity, and reduce intestinal ROS production [30]. In addition, the GR treatment alters the expression pattern of genes encoding insulin-like signaling pathways, which play a key role in longevity control [11].

Geng Nian Chun (GNC) consists of 12 traditional Chinese medicines (i.e., Radix Rehmanniae, Rhizoma Coptidis, Radix Paeoniae Alba, Rhizoma Anemarrhenae, Cistanche salsa, and Radix Morindae officinalis [63]), which are used to improve functional loss associated with aging. The wild-type nematodes treated with GNC show prolonged survival time under normal and oxidative stress conditions, but the nematodes with daf-16 mutation do not have antioxidant stress effects. This result suggests that the life extension and antioxidant stress effects of GNC are realized through the daf-16/FOXO-dependent pathway. Further study shows that GNC cannot prolong the lifespan of the mutant strains of daf-2, age-1, and daf-16. This result implies that GNC may extend the lifespan of nematodes through the IIS pathway and has a potential use in the development of antiaging drugs [31].

Rehmannia glutinosa (PRG), a TCM with remarkable medical value, has anti-inflammatory, antibacterial, and anticancer activities and can protect cardiovascular function. Recent studies have found that the main component of ripe PRG is a neutral polysaccharide. Among them, the neutral polysaccharide of NPRG, a functional pharmaceutical component, can regulate $d a f-2$ and $d a f-16$ genes through the 


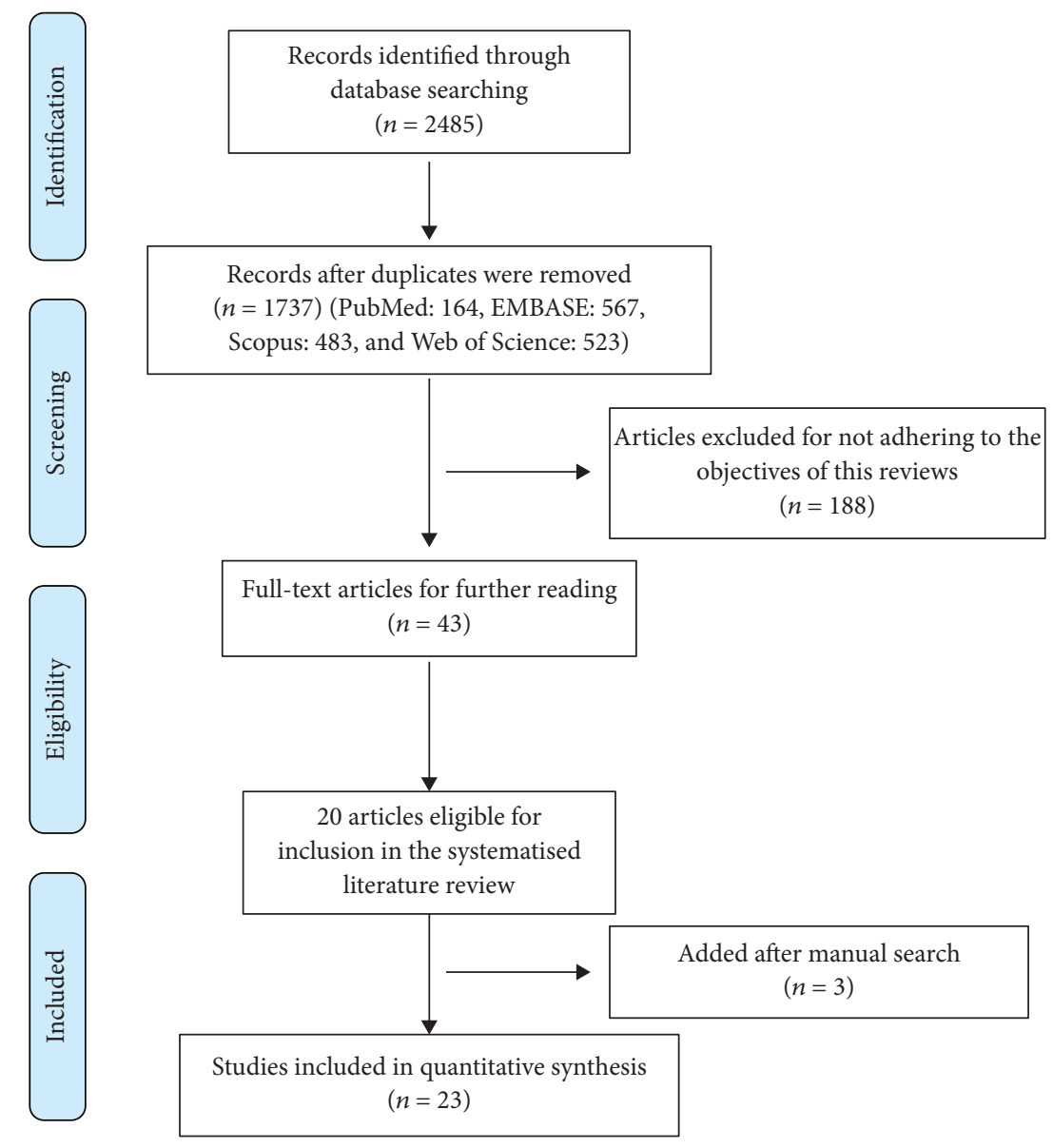

Figures 1: A flowchart of literature search and selection in this review is described in detail.<smiles>O=C(/C=C/c1ccc(O)c(O)c1)OC1(C(=O)O)CC(O)C(O)C(O)C1</smiles>

1, 3-Dicaffeoylquinic acid<smiles>COc1ccc(-c2cc(=O)c3c(O)cc(Cl)cc3o2)cc1</smiles><smiles>O=C(C=Cc1ccc(O)c(Cl)c1)CC1CC(O)C(O)CC1C(=O)O</smiles>

Chlorogenic acid<smiles>C=CC1C2=CCOC(=O)C2=CO[C@@H]1O[C@H]1OC(CO)[C@@H](O)[C@H](O)[C@H]1O</smiles>

Gentiopicroside acid

FIgUre 2: Chemical structures of some of the main components of TCM.

IIS pathway, thereby enhancing the antistress ability and prolonging the lifespan of nematode worms [32].

Lycium barbarum polysaccharide (LBP) is one of the main active components of L. barbarum. LBP can prolong the lifespan of nematodes, improve their resistance to a harsh environment, enhance their reproductive ability, and ensure the integrity of nematode muscles. The RNAi gene is silenced with mutant nematode strains, and mRNA expression levels are measured. Using mutated nematode strains, RNAi silenced daf-16 genes of N2 and Sir-2.1 mutants, and measuring their mRNA expression levels, it was demonstrated that the life-prolonging activity of LBP is achieved by regulating sir-2.1, daf-12, and daf-16 genes [33].
As a powerful antidote and immune system booster, juniper is often used to treat opportunistic infections [64]. Juniper essential oil (JBEO) extracted from juniper has certain antioxidant and anti-free-radical activities in vitro [65]. In addition, JBEO can prolong the lifespan of nematodes in vivo and improve the resistance of nematodes to oxidative stress and heat stress. Meanwhile, the increased expression of sod-3 (39.49\%) and gst-4 (25.13\%) is observed. In exploring the mechanism of JBEO life-prolonging activity, conserved transcription factors (i.e., daf-16, skn-1, and $h s f-1)$ are found to be involved in this process [34].

Tambulin is a hydroxy iodic flavanol separated from Zanthoxylum armatum. Aging is a major cause of neurodegenerative diseases, including Huntington's syndrome, 
Parkinson's disease, and Alzheimer's disease [6,66]. The lifespan and stress tolerance of nematodes are significantly improved by tambulin treatment, and this phenomenon is accompanied by the remission of aging biomarkers, such as lipofuscin and protein carbonyl. Consistent with the decreased ROS level, the tambulin treatment results in the upregulated mRNA expression of ROS-removing genes, namely, sod-1, sod-3, and ctl-2. Tambulin therapy is shown to be effective in the treatment of Parkinson's disease; decreasing alpha-synuclein levels and lipid accumulation; improving motor behavior; elevating dopamine levels [35].

Previous studies have shown that Hibiscus sabdariffa $L$. can significantly reduce skin aging markers in female patients [67] and improve short- and long-term memory deficits in elderly albino mice [49]. According to recent studies that have used nematodes as animal models, $H$. sabdariffa $L$. extracts (HSE) can remarkably prolong the lifespan of nematodes in vivo and slow down the age-dependent decline in locomotor capacity [36]. This role of HSE depends on key transcription factors daf-16 and $s k n-1$. At the same time, HSE increases the intracellular ROS level, indicating that HSE has prooxidation activity. HSE is resistant to the toxicity induced by the amyloid-beta protein and has a life-prolonging effect.

Polygonum multiflorum extract (PME) can reduce the accumulation of lipofuscin in the liver and brain of mice [49] and has a neuroprotective effect on the degeneration of the substantia nigra striatum. Simultaneously, PME has an antioxidant effect, and nematodes exposed to PME have enhanced antioxidant stress ability. In addition, PME can prolong the average lifespan of C. elegans and reduce the accumulation of ROS by regulating daf-16 and sir-2.1 [37].

At present, the clinical application of Ganoderma lucidum is limited to adjuvant therapy, such as regulating immune response and reducing inflammatory response $[68,69]$, but its pharmacological mechanism remains unclear. Recent studies have shown that G. lucidum can effectively improve the resistance of nematodes to paraquatinduced oxidative stress and heavy metal stress and can extend their lifespan. The protective effect of G. lucidum on nematodes may be exerted through dietary restriction and the mTOR/S6K signaling pathway, whereas the lifespan extension of nematodes is dependent on the germline signaling pathway [38].

Astragalus armor glycoside IV (AS-IV) is isolated from dry Astragalus root and is widely used in the treatment of inflammation, viruses, and even cancer [70]. The lifespan of AS-IV-treated nematodes is prolonged under oxidative stress, heat stress, and normal conditions. At the same time, AS-IV can enhance the activities of superoxide dismutase (SOD) and peroxidase, increase the content of glutamic acid, and decrease the content of glucose in nematodes. Interestingly, the lifespans of sod-1, sod-2, sod-3, sod-4, sod-5, ctl$1, c t l-2, c t l-3$, and daf-16 mutants do not change with AS-IV treatment. These results indicate that the life-prolonging activity of AS-IV is achieved by improving the age-related functional decline and antioxidant capacity and partially regulating the activity of the IIS pathway [39].
3.2.2. Effect of TCM or Its Active Components on Delaying Senescence in Other Animal Models or Cells. Aside from the C. elegans model, silkworm, yeast, and other natural aging models with short life cycle are used in antiaging research of TCM or its active ingredients. In addition to the natural aging model, UV-induced senescence cells and hairless mice are commonly used to simulate skin aging; DP cells aging model was used to simulate hair loss; $\mathrm{H}_{2} \mathrm{O}_{2}$-induced HUVECs aging was used to study cardiovascular diseases. In addition, D-galactose-induced aging mice are one of the main means of antiaging drug research. Chinese medicines or their active components have an antiaging effect in the body and a significant inhibitory effect on skin aging.

Snutellaria baicalensis Georgi flowers extract (SFE) is mainly composed of flavonoids that can improve spatial memory ability. Studies have shown that SFE can significantly regulate malondialdehyde (MDA), SOD, and advanced glycation end products and significantly improve liver pathological abnormalities. In addition, SFE significantly increases the levels of D-glutamine and D-glutamate. SFE is speculated to play an antiaging role by regulating the glutamine-glutamate metabolism pathway [40].

The water extract of Rhodiola Rosea can significantly extend the lifespan of silkworms and enhance their resistance to heat stress and hunger without changing their food intake, body weight, or fertility. At the same time, $R$. rosea treatment increases the activities of glutathione S-transferase and catalase and changes the contents of glutathione and MDA. In addition, the mRNA expression of BmFOXO is significantly increased after $R$. rosea treatment [41]. BmFOXO is a key transcription factor in the IIS pathway and acts downstream of the IIS pathway [71]. Therefore, the IIS may be involved in the prolonged silkworm life induced by $R$. rosea.

Gentiopicroside (GPS), which is isolated from Gentiana rigescens, is an iridoid glycoside compound with an antiaging effect. GPS can effectively prolong the replication and chronological lifespan of yeast, improve the survival rate of yeast under oxidative stress, and enhance the activities of catalase, SOD, and glutathione peroxidase. In addition, the levels of free GFP in the cytoplasm, free GFP in the mitochondria, and ubiquitin are significantly increased after GPS treatment. Autophagy, especially mitochondrial autophagy, and antioxidant stress may be involved in the GPS-induced life extension [42].

The aqueous extract (WEZ) and volatile oil (VOZ) of Zanthoxylum bungeanum Maxim can alleviate memory impairment and protect against D-galactose-induced hippocampal nerve injury. In addition, WEZ and VOZ enhance the activity of phosphatidylinositol 3-kinase (PI3K)/proteinase B (Akt). The evident therapeutic effect of $Z$. bungeanum on memory disorders may be related to the activation of the PI3K/Akt signaling pathway [43].

Male mice are induced to senescence after the subcutaneous injection of D-galactose for 42 days. Treatment with Nigella sativa fixed oil reduces the lipid peroxidation in mice. $N$. sativa fixed oil ( 0.1 and $0.2 \mathrm{~mL} / \mathrm{kg})$ significantly restores the $\mathrm{GSH}$ content and reduces $\mathrm{Bax} / \mathrm{Bcl} 2$ levels. In addition, $0.1 \mathrm{~mL} / \mathrm{kg}$ N. sativa fixed oil downregulates the expression of 
caspase-3 protein in the brain and liver of aging mice. $N$. sativa fixed oil may play an antiaging role in D-galactoseinduced aging models through its antioxidant activity and antiapoptotic effects [44].

$\mathrm{HaCaT}$ cells and human dermal fibroblasts (HDF) are induced by UV light, and cells are aged. Safflower seed oil (Charthamus tintorius L., SSO) and its main component acacetin (5,7-dihydroxy-4'-methoxyflavone) inhibit the expression of matrix metalloproteinases (MMP-1) in aging $\mathrm{HaCaT}$ and HDF cells [72]. MMP-1 plays an important role in collagen degradation and wrinkle formation. SSO and acacetin may inhibit skin aging through MMP-1 [45].

UV radiation can produce ROS that damages the skin structure and causes skin aging. Skin aging can be simulated through the UV irradiation of hairless mice [73]. The treatment of pomegranate juice concentrated powder (PCP) can significantly improve skin wrinkling and edema caused by photoaging and significantly increase the content of skin moisture, type I collagen, and hyaluronic acid. In addition. glutathione consumption is inhibited by PCP therapy. Moreover, PCP decreases the expression levels of MMP-1, 9, and 13 and NOX2 mRNAs in the skin of mice exposed to UV. PCP has a good protective effect on skin aging induced by UVB [46].

Agastache rugosa Kuntze, a perennial herb, belongs to the mint family (Lamiaceae). A. rugosa has been shown to contain several kinds of flavonoids, including acacetin-7-O- $\beta$-Dglucopyranoside (tilianin), acacetin, linarin, agastachoside, and rosmarinic acid [74]. Hot water extract of Agastache rugosa Kuntze leaf (ARE) can attenuate the UV-B-induced ROS generation and reduce the activity and protein level of ProMMP-2 and - 9 induced by UV-B and increase the activity level of total GSH and total SOD reduced by UV-B in HaCaT keratinocytes [47]. The protective effect of ARE on UV-Binduced photoaging in $\mathrm{HaCaT}$ keratinocytes may be based on the upregulation of antioxidant components, including total GSH and SOD.

DP cells play an important role in the occurrence and development of androgenetic alopecia (AGA) [75]. Aging DP cells may participate in the occurrence of AGA by upregulating the expression of SRD5A2. Plumbago zeylanica (also known as Chitrak) and its components can promote the growth of DP cells and downregulate the expression of SRD5A2 in DP cells [48]. It is speculated that Plumbago zeylanica may be used to treat AGA.

Endothelial cell aging is a major risk factor for inducing cardiovascular disease (CVD) [76, 77]. The vascular endothelial dysfunction induced by hydrogen peroxide $\left(\mathrm{H}_{2} \mathrm{O}_{2}\right)$ is partly responsible for the development of aging [78, 79]. Ginsenoside RB1 (RB1) is the main component of ginsenoside, which has biological activities such as relieving oxidative stress, antiobesity, and antiinflammation [80-82]. Studies have shown that RB1 restored the $\mathrm{H}_{2} \mathrm{O}_{2}$-induced reduction in SIRT1 expression and activated AMPK phosphorylation to protect HuVecs from $\mathrm{H}_{2} \mathrm{O}_{2}$-induced senescence [81]. This provides a new way to prevent cardiovascular diseases associated with aging.
3.3. Methodological Quality/Risk of Bias. Figure 3 introduces the methodological features of this review. In all papers, the frequency of TCM treatment and age and strain of experimental animals are described in detail. Experiments using C. elegans and silkworm as animal models do not need the approval of the animal protection evaluation committee, and experiments requiring support have already been approved. The main purpose and findings of the study have been accurately expressed in all articles.

Figures 4 and 5 present the year and country of publication of each article in the review. From the perspective of expression years, the number of articles published is increasing yearly. As a traditional treatment method, TCM is gaining new vitality, and its antiaging effect is also attracting increasing attention. In terms of publishing countries, Chinese herbal medicine is widely studied in China, Japan, South Korea, Germany, India, and Iran. Chinese herbal medicine has been widely valued worldwide, and its in-depth research has promoted the development of new drugs based on the natural products of plants.

\section{Conclusion}

This paper reviews the antiaging and antioxidant potentials of TCM or its active components as natural products. TCM or its active components play a significant antiaging effect in various aging models. Considering the rigor of this review, although improvement is still needed in some aspects, the quality of the articles included in the review is of a medium or high level.

The IIS pathway is the first confirmed pathway to regulate aging [83]. From humans to nematodes, this longevity control pathway has always been highly conserved [84, 85]. The IIS pathway acts through the PI3K/Akt and is activated by insulin peptides. Age-1 and daf-2 encode phosphoinositol-3 kinase (PI3K) and insulin/IGF-1 receptors $[86,87]$, respectively, which are key upstream components of IIS. Decreased daf-2 function leads to inactivation of downstream kinase cascades beginning with AGE-1/PI3K [88]. Downregulation of age-1 inactivates 3-phosphoinositol-dependent kinase 1 (PDK-1) [89]. This, in turn, downregulates the Akt/protein kinase B (PKB) family members, AKT-1 and AKT-2 [89]. The PI (3, 4, 5) $\mathrm{P} 3 / \mathrm{PI}(4,5) \mathrm{P} 2$ ratio can also be decreased by the activation of DAF-18/phosphatase and tensin (PTEN) phosphatase, which mediates dephosphorylation of PI $(3,4,5)$ P3 and increases lifespan [88, 90-92]. FOXO/DAF-16 plays an important role in the PI3K/Akt pathway. Under weak insulin signaling conditions, unphosphorylated FOXO/DAF-16 is transported to the nucleus to promote the transcription of genes related to longevity in the organism $[93,94]$. Through a systematic review of 20 studies, we have found that most of the antiaging effects of TCM are involved in the IIS pathway. Coix seed essential oil, clove essential oil, Lonicera japonica crude extractions, Glycyrrhizae Radix crude extractions, Gengnianchun aqueous extractions, Rehmannia glutinosa neutral polysaccharides, Lycium barbarum neutral polysaccharides, juniper berry (Juniperus communis L.) essential oil, Zanthoxyllum aramatum natural flavonol, Hibiscus sabdariffa L., Polygonum multiflorum aqueous extract, and Astragalus 


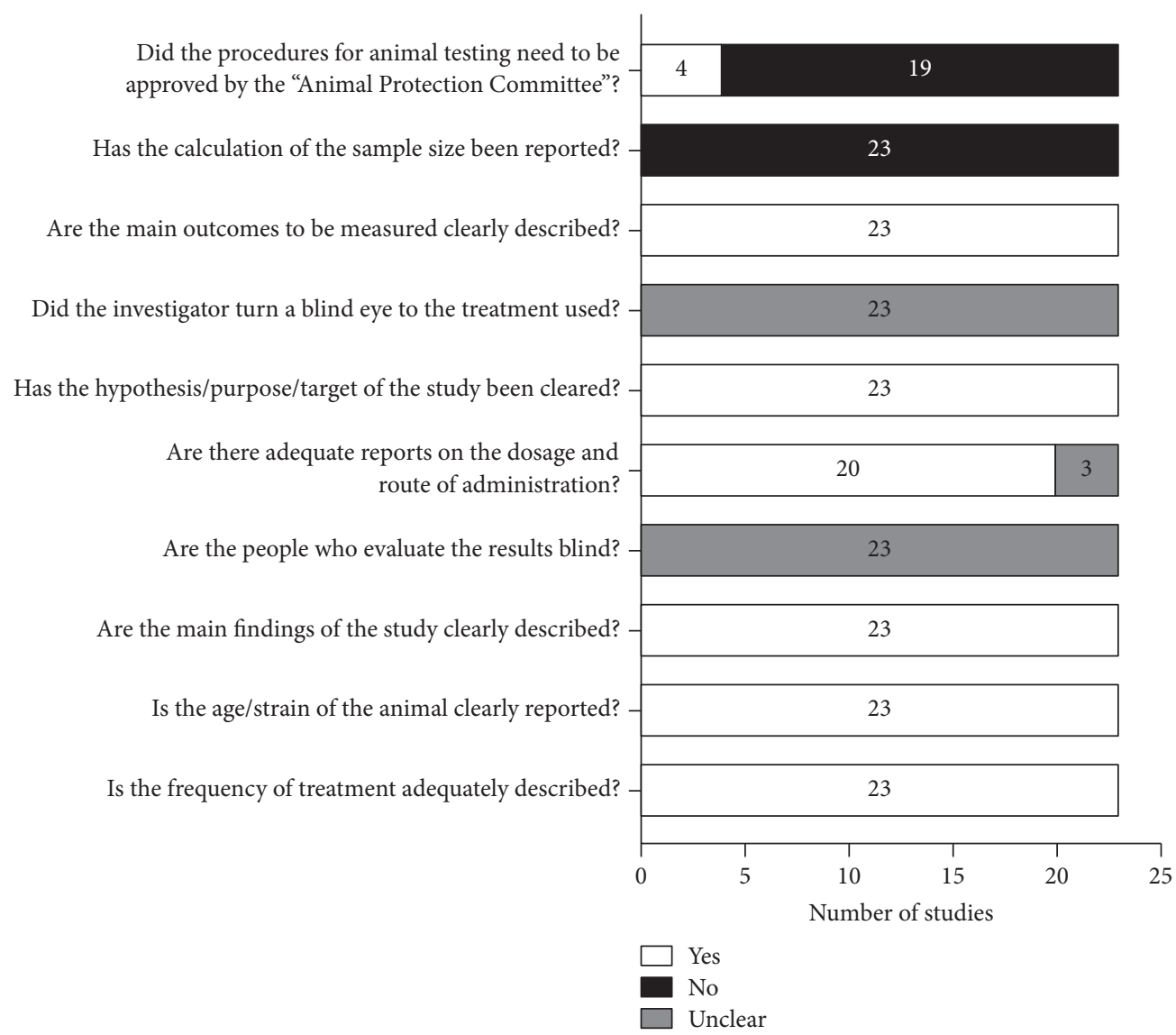

FIGURE 3: Methodological quality of included in vivo studies.

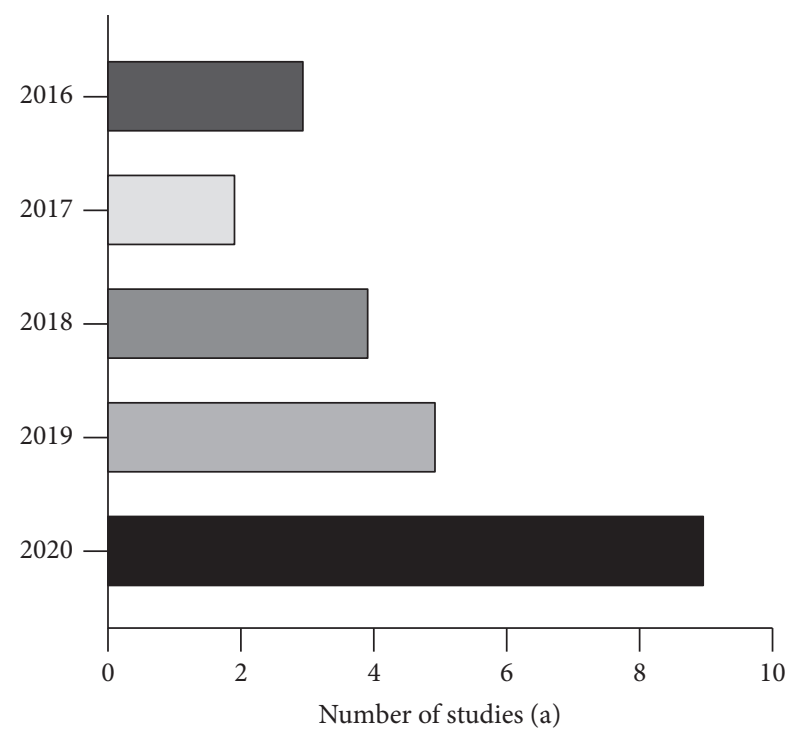

FIGURE 4: The year of publication of the review article.

membranaceus astragaloside IV (AS-IV) can all increase the expression of daf-16 [22-32,34]. Hsf-1 expression in C. elegans was increased after treatment with coix seed essential oil and Lonicera japonica crude extractions [23,24]. After treatment with Rehmannia glutinosa neutral polysaccharides, Lycium barbarum neutral polysaccharides, and Lonicera japonica

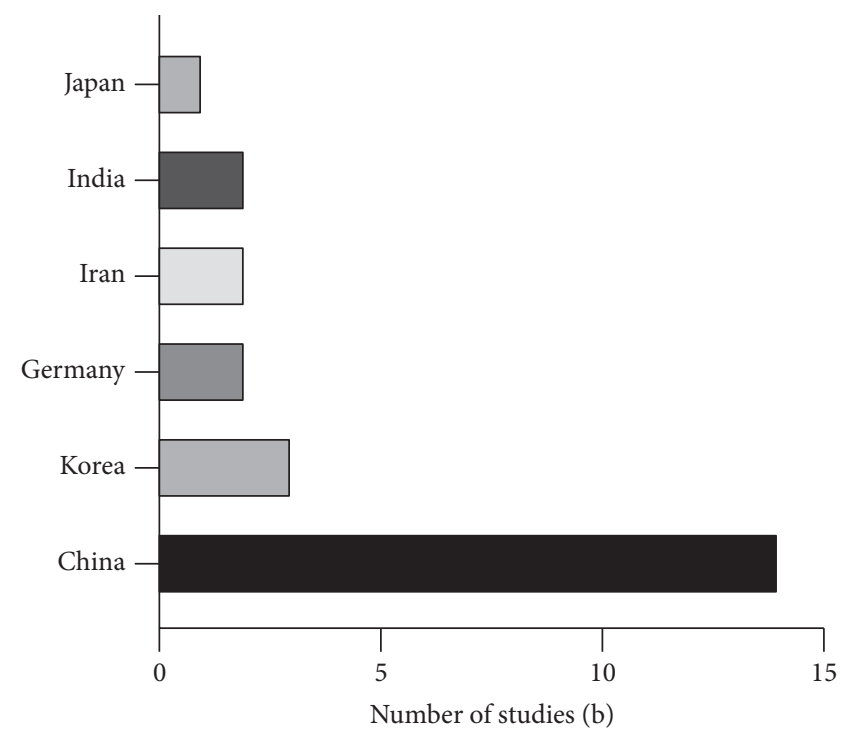

FIGURE 5: The country of publication of the review article.

crude extractions, the expression pattern of $d a f-2$ in C. elegans was low [24, 27, 28].

Sirtuin family is a kind of nicotinamide dinucleotide (NAD+) dependent deacylase, which plays a significant role in preventing diseases and delaying senility [95, 96]. Levels of sirtuins, including silencing information regulator 1 
(SIRT1) and silencing information regulator 6 (SIRT6) but not silencing information regulator 2 (SIRT2), have been reported to decline in senescent cells exposed to oxidants in mouse embryonic fibroblasts, lung epithelial cells, human endothelial cells, and macrophages $[97,98]$. Sirtuin plays an active role in maintaining gene integrity [96], regulating telomere reverse transcriptase expression [99], promoting DNA repair [100-102], changing the expression of senescence related genes, and maintaining stem cell selfrenewal $[103,104]$. Sirtuin also regulates body longevity. The life span of the budding yeast Saccharomyces cerevisiae, nematodes, Drosophila melanogaster, and mice would be prolonged with the increase of sirtuin levels [105-108]. Sirtuins were found to interact with all major longevity conserved pathways, such as AMP-activated protein kinase (AMPK), insulin/IGF-1 signaling pathway (IIS), target of rapamycin (TOR), and forkhead box $\mathrm{O}$ (FOXO) [109-111]. It was found that the expression level of sir-2.1 gene was increased after LBP treatment, and the longevity prolonging effect of LBP on the sir-2.1 mutant was shorter than that of N2. This implies that the lifeextending effect of LBP requires sir-2.1 [33]. In addition, Polygonum multiflorum can prolong the life span of wildtype Caenorhabditis elegans and improve its ability to resist paraquat stress, but not the SIR-2.1-deficient strain [37]. Curcumin pretreatment significantly reduced $\mathrm{H}_{2} \mathrm{O}_{2}$ induced premature senescence of HUVECs, which was characterized by decreased percentage of senescence associated $\beta$-galactosidase positive cells, enhanced cell division ability, and decreased expression of senescence associated protein p21 [112]. SIRT1 short interfering RNA (siRNA) inhibition of SIRT1 can reduce the expression and phosphorylation of eNOS and eliminate the protective effect of curcumin on $\mathrm{H}_{2} \mathrm{O}_{2}$-induced premature senescence. These results suggested that curcumin could reduce the premature senility of HUVECs induced by oxidative stress by activating SIRT1. It has been found that ginsenoside can reduce the positive rate of $\beta$-galactosidase in $\mathrm{H}_{2} \mathrm{O}_{2}$-induced HUVEC. In addition, $\mathrm{RB} 1$ reduced eNOS acetylation and promoted more NO production, accompanied by an increase in SIRT1 expression. Interestingly, after SIRT1 was knocked out, the effect of RB1 on HUVEC aging was weakened [113].

The continuous research on the antiaging effect of TCM and the exploration of the antiaging pathway will be helpful in the research and development of new antiaging drugs.

\section{Conflicts of Interest}

The authors declare that they have no conflicts of interest.

\section{Acknowledgments}

This research was supported by the Key Laboratory of Precision Infectious Diseases of Jilin Province (grant no. 20200601011JC) and was funded by the Development of Plant Antibacterial Peptide Series Health Products (grant no. 20200404046YY), Jilin Province Chinese Patent Medicine Secondary Development Technology Innovation Center, and Innovation Capability Construction Project of Jilin Provincial Development and Reform Commission (grant no. 2019C030).

\section{References}

[1] G. De Winter, "Aging as disease," Medicine, Health Care and Philosophy, vol. 18, no. 2, pp. 237-243, 2015.

[2] J. P. da Costa, R. Vitorino, G. M. Silva, C. Vogel, A. C. Duarte, and T. Rocha-Santos, "A synopsis on agingtheories, mechanisms and future prospects," Ageing Research Reviews, vol. 29, pp. 90-112, 2016.

[3] A. Wysokiński, T. Sobów, I. Kłoszewska, and T. Kostka, "Mechanisms of the anorexia of aging-a review," Age (Dordrecht, Netherlands), vol. 37, no. 4, p. 9821, 2015.

[4] "Alzheimer's disease facts and figures, Alzheimer's \& dementia," The Journal of the Alzheimer's Association, vol. 12, no. 4, pp. 459-509, 2016.

[5] K. W. Faiz and L. Pihlstrøm, "Parkinsons sykdom og parkinsonisme," Tidsskrift for Den Norske Legeforening, vol. 137, no. 4, p. 298, 2017.

[6] T. Wyss-Coray, "Ageing, neurodegeneration and brain rejuvenation,” Nature, vol. 539, no. 7628, pp. 180-186, 2016.

[7] L. Partridge, J. Deelen, and P. E. Slagboom, "Facing up to the global challenges of ageing," Nature, vol. 561, no. 7721, pp. 45-56, 2018.

[8] W. Chen, X. Shen, Y. Hu et al., "Surface functionalization of titanium implants with chitosan-catechol conjugate for suppression of ROS-induced cells damage and improvement of osteogenesis,” Biomaterials, vol. 114, pp. 82-96, 2017.

[9] M. Suzuki, C. Bandoski, and J. D. Bartlett, "Fluoride induces oxidative damage and SIRT1/autophagy through ROS-mediated JNK signaling," Free Radical Biology and Medicine, vol. 89, pp. 369-378, 2015.

[10] H. Zhang, K. J. A. Davies, and H. J. Forman, "Oxidative stress response and Nrf2 signaling in aging," Free Radical Biology and Medicine, vol. 88, no. Pt B, pp. 314-336, 2015.

[11] T. Sasako and K. Ueki, "[Insulin/IGF-1 signaling and aging], Nihon rinsho," Japanese Journal of Clinical Medicine, vol. 74, no. 9, pp. 1435-1440, 2016.

[12] I. K. H. Hadem, T. Majaw, B. Kharbuli, and R. Sharma, "Beneficial effects of dietary restriction in aging brain," Journal of Chemical Neuroanatomy, vol. 95, pp. 123-133, 2019.

[13] M. Podhorecka, B. Ibanez, and A. Dmoszyńska, "Metforminits potential anti-cancer and anti-aging effects," Postepy Higieny I Medycyny Doswiadczalnej (Online), vol. 71, pp. 170-175, 2017.

[14] T. Phillips and C. Leeuwenburgh, "Lifelong aspirin supplementation as a means to extending life span," Rejuvenation Research, vol. 7, no. 4, pp. 243-252, 2004.

[15] S. T. de Vries, P. Denig, C. Ekhart, P. G. M. Mol, and E. P. van Puijenbroek, "Sex differences in adverse drug reactions of metformin: a longitudinal survey study," Drug Safety, vol. 43, no. 5, pp. 489-495, 2020.

[16] S. C. Johnston, J. J. Elm, J. D. Easton et al., "Time course for benefit and risk of clopidogrel and aspirin after acute transient ischemic attack and minor ischemic stroke," Circulation, vol. 140, no. 8, pp. 658-664, 2019.

[17] L. Ang, H. W. Lee, A. Kim, J. A. Lee, J. Zhang, and M. S. Lee, "Herbal medicine for treatment of children diagnosed with COVID-19: a review of guidelines," Complementary Therapies in Clinical Practice, vol. 39, p. 101174, 2020. 
[18] H. Luo, C. T. Vong, H. Chen et al., "Naturally occurring anticancer compounds: shining from Chinese herbal medicine," Chinese Medicine, vol. 14, p. 48, 2019.

[19] B. Yang, Y. Xie, M. Guo, M. H. Rosner, H. Yang, and C. Ronco, "Nephrotoxicity and Chinese herbal medicine," Clinical Journal of the American Society of Nephrology, vol. 13, no. 10, pp. 1605-1611, 2018.

[20] M. Morvaridzadeh, S. Fazelian, S. Agah et al., "Effect of ginger (Zingiber officinale) on inflammatory markers: a systematic review and meta-analysis of randomized controlled trials," Cytokine, vol. 135, p. 155224, 2020.

[21] J. Heshmati, A. Moini, M. Sepidarkish et al., "Effects of curcumin supplementation on blood glucose, insulin resistance and androgens in patients with polycystic ovary syndrome: a randomized double-blind placebo-controlled clinical trial," Phytomedicine, vol. 80, p. 153395, 2021.

[22] F. Wan, D. Zhi, D. Liu et al., "Lifespan extension in Caenorhabiditis elegans by several traditional Chinese medicine formulas," Biogerontology, vol. 15, no. 4, pp. 377-387, 2014.

[23] Z. Ning, Y. Li, D. Liu et al., "Tetrahydroxystilbene glucoside delayed senile symptoms in old mice via regulation of the AMPK/SIRT1/PGC-1 $\alpha$ signaling cascade," Gerontology, vol. 64 , no. 5, pp. 457-465, 2018.

[24] A. Marchese, C. R. Arciola, R. Barbieri et al., "Update on monoterpenes as antimicrobial agents: a particular focus on p-cymene," Materials (Basel, Switzerland), vol. 10, no. 8, 2017.

[25] L. L. Silva, Q. I. Garlet, S. C. Benovit et al., "Sedative and anesthetic activities of the essential oils of Hyptis mutabilis (Rich.) Briq. and their isolated components in silver catfish (Rhamdia quelen)," Brazilian Journal of Medical and Biological Research, vol. 46, no. 9, pp. 771-779, 2013.

[26] D. Moher, A. Liberati, J. Tetzlaff, and D. G. Altman, "Preferred reporting items for systematic reviews and metaanalyses: the PRISMA statement," BMJ, vol. 339, no. jul21 1, p. b2535, 2009.

[27] L. Zhang, B. Gu, and Y. Wang, "Clove essential oil confers antioxidant activity and lifespan extension in C. elegans via the DAF-16/FOXO transcription factor," Comparative Biochemistry and Physiology Part C: Toxicology \& Pharmacology, vol. 242, p. 108938, 2020.

[28] X.-Y. Chen, D.-C. Liao, Y.-T. Yu et al., "Coix seed oil prolongs lifespan and enhances stress resistance in Caenorhabditis elegans," Biogerontology, vol. 21, no. 2, pp. 245-256, 2020.

[29] Z.-Z. Yang, Y.-T. Yu, H.-R. Lin, D.-C. Liao, X.-H. Cui, and H.-B. Wang, "Lonicera japonica extends lifespan and healthspan in Caenorhabditis elegans," Free Radical Biology and Medicine, vol. 129, pp. 310-322, 2018.

[30] Q. Ruan, Y. Qiao, Y. Zhao et al., "Beneficial effects of Glycyrrhizae radix extract in preventing oxidative damage and extending the lifespan of Caenorhabditis elegans," Journal of Ethnopharmacology, vol. 177, pp. 101-110, 2016.

[31] F. Meng, J. Li, Y. Rao, W. Wang, and Y. Fu, "Gengnianchun extends the lifespan of Caenorhabditis elegans via the insulin/ IGF-1 signalling pathway," Oxidative Medicine and Cellular Longevity, vol. 2018, Article ID 4740739, 10 pages, 2018.

[32] Y. Yuan, N. Kang, Q. Li, Y. Zhang, Y. Liu, and P. Tan, "Study of the effect of neutral polysaccharides from Rehmannia glutinosa on lifespan of Caenorhabditis elegans," Molecules, vol. 24, no. 24, 2019.

[33] Z. Zhang, Y. Zhou, H. Fan et al., "Effects of lycium barbarum polysaccharides on health and aging of C. elegans depend on
Daf-12/daf-16," Oxidative Medicine and Cellular Longevity, vol. 2019, Article ID 6379493, 14 pages, 2019.

[34] S. Pandey, S. Tiwari, A. Kumar et al., "Antioxidant and antiaging potential of Juniper berry (Juniperus communis L.) essential oil in Caenorhabditis elegans model system," Industrial Crops and Products, vol. 120, pp. 113-122, 2018.

[35] T. Pandey, S. R. Sammi, Z. Nooreen et al., "Anti-ageing and anti-Parkinsonian effects of natural flavonol, tambulin from Zanthoxyllum aramatum promotes longevity in Caenorhabditis elegans," Experimental Gerontology, vol. 120, pp. 50-61, 2019.

[36] K. Koch, N. Weldle, S. Baier, C. Büchter, and W. Wätjen, "Hibiscus sabdariffa L. extract prolongs lifespan and protects against amyloid- $\beta$ toxicity in Caenorhabditis elegans: involvement of the FoxO and Nrf2 orthologues DAF-16 and SKN-1," European Journal of Nutrition, vol. 59, no. 1, pp. 137-150, 2020.

[37] C. Saier, C. Büchter, K. Koch, and W. Wätjen, "Polygonum multiflorum extract exerts antioxidative effects and increases life span and stress resistance in the model organism Caenorhabditis elegans via DAF-16 and SIR-2.1," Plants (Basel, Switzerland), vol. 7, no. 3, 2018.

[38] V. T. Cuong, W. Chen, J. Shi et al., "The anti-oxidation and anti-aging effects of Ganoderma lucidum in Caenorhabditis elegans," Experimental Gerontology, vol. 117, pp. 99-105, 2019.

[39] J. Zhang, X. Xue, Y. Qiao et al., “Astragaloside IV extends lifespan of caenorhabditis elegans by improving age-related functional declines and triggering antioxidant responses," Rejuvenation Research, vol. 24, 2021.

[40] J. Song, Y.-z. Zhou, Y.-y. Pang, L. Gao, G.-h. Du, and X.-m. Qin, "The anti-aging effect of Scutellaria baicalensis Georgi flowers extract by regulating the glutamine-glutamate metabolic pathway in d-galactose induced aging rats," Experimental Gerontology, vol. 134, p. 110843, 2020.

[41] C. Chen, J. Song, M. Chen et al., "Rhodiola rosea extends lifespan and improves stress tolerance in silkworm, Bombyx mori," Biogerontology, vol. 17, no. 2, pp. 373-381, 2016.

[42] Q. Liu, L. Cheng, A. Matsuura, L. Xiang, and J. Qi, "Gentiopicroside, a secoiridoid glycoside from Gentiana rigescens franch, extends the lifespan of yeast via inducing mitophagy and antioxidative stress," Oxidative Medicine and Cellular Longevity, vol. 2020, Article ID 9125752, 12 pages, 2020.

[43] M. Zhao, X. Tang, D. Gong, P. Xia, F. Wang, and S. Xu, "Bungeanum improves cognitive dysfunction and neurological deficits in D-galactose-induced aging mice via activating PI3K/Akt/Nrf2 signaling pathway," Frontiers in Pharmacology, vol. 11, p. 71, 2020.

[44] M. J. Shahroudi, S. Mehri, and H. Hosseinzadeh, "Anti-aging effect of Nigella sativa fixed oil on D-galactose-induced aging in mice," Journal of Pharmacopuncture, vol. 20, no. 1, pp. 29-35, 2017.

[45] E. H. Jeong, H. Yang, J.-E. Kim, and K. W. Lee, "Safflower seed oil and its active compound acacetin inhibit UVB-induced skin photoaging," Journal of Microbiology and Biotechnology, vol. 30, no. 10, pp. 1567-1573, 2020.

[46] S.-J. Kang, B.-R. Choi, S.-H. Kim et al., "Beneficial effects of dried pomegranate juice concentrated powder on ultraviolet B-induced skin photoaging in hairless mice," Experimental and Therapeutic Medicine, vol. 14, no. 2, pp. 1023-1036, 2017.

[47] Y. Oh, H.-W. Lim, Y.-H. Huang et al., "Attenuating properties of Agastache rugosa leaf extract against ultraviolet-B-induced photoaging via up-regulating glutathione and superoxide dismutase in a human keratinocyte cell 
line," Journal of Photochemistry and Photobiology B: Biology, vol. 163, pp. 170-176, 2016.

[48] N. Yamada, K. Miki, Y. Yamaguchi et al., "Extract of Plumbago zeylanica enhances the growth of hair follicle dermal papilla cells with down-regulation of $5 \alpha$-reductase type II," Journal of Cosmetic Dermatology, vol. 19, no. 11, pp. 3083-3090, 2020.

[49] Z. Zheng, M. Wang, C. Cheng et al., "Ginsenoside Rb1 reduces $\mathrm{H} 2 \mathrm{O} 2$-induced HUVEC dysfunction by stimulating the sirtuin-1/AMP-activated protein kinase pathway," Molecular Medicine Reports, vol. 22, no. 1, pp. 247-256, 2020.

[50] C. R. Hooijmans, M. M. Rovers, R. B. de Vries, M. Leenaars, M. Ritskes-Hoitinga, and M. W. Langendam, "SYRCLE's risk of bias tool for animal studies," BMC Medical Research Methodology, vol. 14, p. 43, 2014.

[51] X. Zeng, Y. Zhang, J. S. W. Kwong et al., "The methodological quality assessment tools for preclinical and clinical studies, systematic review and meta-analysis, and clinical practice guideline: a systematic review," Journal of Evidence-Based Medicine, vol. 8, no. 1, pp. 2-10, 2015.

[52] D. Moher, A. Liberati, J. Tetzlaff, and D. G. Altman, "Preferred reporting items for systematic reviews and metaanalyses: the PRISMA statement," PLoS Medicine, vol. 6, no. 7, Article ID e1000097, 2009.

[53] Z. Qin, R. Johnsen, S. Yu, J. S.-C. Chu, D. L. Baillie, and N. Chen, "Genomic identification and functional characterization of essential genes in Caenorhabditis elegans," G3 Genes|Genomes|Genetics, vol. 8, no. 3, pp. 981-997, 2018.

[54] M. Hertweck, T. Hoppe, and R. Baumeister, "C. elegans, a model for aging with high-throughput capacity," Experimental Gerontology, vol. 38, no. 3, pp. 345-346, 2003.

[55] F. Yu, J. Gao, Y. Zeng, and C.-X. Liu, "Effects of adlay seed oil on blood lipids and antioxidant capacity in hyperlipidemic rats," Journal of the Science of Food and Agriculture, vol. 91, no. 10, pp. 1843-1848, 2011.

[56] D. Wang, C. Yang, Z. Wang et al., "Norcantharidin combined with Coix seed oil synergistically induces apoptosis and inhibits hepatocellular carcinoma growth by downregulating regulatory $\mathrm{T}$ cells accumulation," Scientific Reports, vol. 7, no. 1, p. 9373, 2017.

[57] E. B. Lee, M. M. Xing, and D. K. Kim, "Lifespan-extending and stress resistance properties of brazilin from Caesalpinia sappan in Caenorhabditis elegans," Archives of Pharmacal Research, vol. 40, no. 7, pp. 825-835, 2017.

[58] X. Shang, H. Pan, M. Li, X. Miao, and H. Ding, "Lonicera japonica Thunb.: ethnopharmacology, phytochemistry and pharmacology of an important traditional Chinese medicine," Journal of Ethnopharmacology, vol. 138, no. 1, pp. 1-21, 2011.

[59] M. N. Asl and H. Hosseinzadeh, "Review of pharmacological effects ofGlycyrrhiza sp. and its bioactive compounds," Phytotherapy Research, vol. 22, no. 6, pp. 709-724, 2008.

[60] Z. Jin, Z. B. Chen, H. Cao, and J. Shen, "Clinical trial of compound Glycyrrhizin injection for the treatment of radiation-induced liver disease," Chinese Journal of Clinical Pharmacology, vol. 26, pp. 183-185, 2010.

[61] Y. Chang and Y. L. Li, "Observation on the therapeutic effect of licorice Xie Heart soup in treating peptic ulcer," Journal of Emergency Traditional Chinese medicine, vol. 23, pp. 1145-1146, 2014.

[62] T. Mao, N. Mao, T. T. Wu, and J. Z. Han, "Clinical observation of compound Glycyrrhizin capsules in treatment 318 patients with skin disease," Chinese Medicine and Pharmacy, vol. 4, pp. 107-108, 2014.
[63] F. Meng, J. Li, W. Wang, and Y. Fu, "Gengnianchun, a traditional Chinese medicine, enhances oxidative stress resistance and lifespan in Caenorhabditis elegans by modulating daf-16/FOXO," Evidence-Based Complementary and Alternative Medicine, vol. 2017, Article ID 8432306, 10 pages, 2017.

[64] M. Höferl, I. Stoilova, E. Schmidt et al., "Chemical composition and antioxidant properties of juniper berry (Juniperus communis L.) essential oil. action of the essential oil on the antioxidant protection of saccharomyces cerevisiae model organism," Antioxidants, vol. 3, no. 1, pp. 81-98, 2014.

[65] T. A. Misharina, M. B. Terenina, and N. I. Krikunova, "Antioxidant properties of essential oils," Prikladnaia Biokhimiia I Mikrobiologiia, vol. 45, no. 6, pp. 710-716, 2009.

[66] A. N. Johnson, "Emergency relief planning and management through dynamic agent-based reallocation and tasking (DART)," Procedia Engineering, vol. 107, pp. 168-171, 2015.

[67] F. Addor, J. Cotta Vieira, and C. Abreu, "Improvement of dermal parameters in aged skin after oral use of a nutrient supplement," Clinical, Cosmetic and Investigational Dermatology, vol. 11, pp. 195-201, 2018.

[68] M. A. Hasnat, M. Pervin, K. M. Cha, S. K. Kim, and B. O. Lim, "Anti-inflammatory activity on mice of extract of Ganoderma lucidum grown on rice via modulation of MAPK and NF- $\kappa$ B pathways," Phytochemistry, vol. 114, pp. 125-136, 2015.

[69] S.-q. Huang and Z.-x. Ning, "Extraction of polysaccharide from Ganoderma lucidum and its immune enhancement activity," International Journal of Biological Macromolecules, vol. 47, no. 3, pp. 336-341, 2010.

[70] F. Xu, W. Q. Cui, Y. Wei et al., “Astragaloside IV inhibits lung cancer progression and metastasis by modulating macrophage polarization through AMPK signaling," Journal of Experimental \& Clinical Cancer Research: CR, vol. 37, no. 1, p. 207, 2018.

[71] A. Eijkelenboom and B. M. T. Burgering, "FOXOs: signalling integrators for homeostasis maintenance," Nature Reviews Molecular Cell Biology, vol. 14, no. 2, pp. 83-97, 2013.

[72] J. S. Roh, J. Y. Han, J. H. Kim, and J. K. Hwang, "Inhibitory effects of active compounds isolated from safflower (Carthamus tinctorius L.) seeds for melanogenesis," Biological and Pharmaceutical Bulletin, vol. 27, no. 12, pp. 1976-1978, 2004.

[73] S. K. Jung, K. W. Lee, H. Y. Kim et al., "Myricetin suppresses UVB-induced wrinkle formation and MMP-9 expression by inhibiting Raf," Biochemical Pharmacology, vol. 79, no. 10, pp. 1455-1461, 2010.

[74] H. Li, Q. Liu, Z. Liu, S. Du, and Z. Deng, "Chemical composition and nematicidal activity of essential oil of Agastache rugosa against Meloidogyne incognita," Molecules, vol. 18, no. 4, pp. 4170-4180, 2013.

[75] S. Inui and S. Itami, "Molecular basis of androgenetic alopecia: from androgen to paracrine mediators through dermal papilla," Journal of Dermatological Science, vol. 61, no. 1, pp. 1-6, 2011.

[76] A. A. Quyyumi, "Endothelial function in health and disease: new insights into the genesis of cardiovascular disease," The American Journal of Medicine, vol. 105, no. 1, pp. 32s-39s, 1998.

[77] T. Minamino, H. Miyauchi, T. Yoshida, Y. Ishida, H. Yoshida, and I. Komuro, "Endothelial cell senescence in human atherosclerosis," Circulation, vol. 105, no. 13, pp. 1541-1544, 2002. 
[78] H. Ota, M. Eto, M. R. Kano et al., "Induction of endothelial nitric oxide synthase, SIRT1, and catalase by statins inhibits endothelial senescence through the Akt pathway," Arteriosclerosis, Thrombosis, and Vascular Biology, vol. 30, no. 11, pp. 2205-2211, 2010.

[79] Y. Ruan, S. Wu, L. Zhang, G. Chen, and W. Lai, "Retarding the senescence of human vascular endothelial cells induced by hydrogen peroxide: effects of 17beta-estradiol (E2) mediated mitochondria protection," Biogerontology, vol. 15, no. 4, pp. 367-375, 2014.

[80] Y. Xiong, L. Shen, K. J. Liu et al., "Antiobesity and antihyperglycemic effects of ginsenoside Rb1 in rats," Diabetes, vol. 59, no. 10, pp. 2505-2512, 2010.

[81] S. Chen, X. Li, Y. Wang et al., "Ginsenoside Rb1 attenuates intestinal ischemia/reperfusion-induced inflammation and oxidative stress via activation of the PI3K/Akt/Nrf2 signaling pathway," Molecular Medicine Reports, vol. 19, no. 5, pp. 3633-3641, 2019.

[82] Q. Sun, Q. T. Meng, Y. Jiang et al., "Protective effect of ginsenoside $\mathrm{Rb} 1$ against intestinal ischemia-reperfusion induced acute renal injury in mice," PLoS One, vol. 8, no. 12, Article ID e80859, 2013.

[83] C. Kenyon, J. Chang, E. Gensch, A. Rudner, and R. Tabtiang, "A C. elegans mutant that lives twice as long as wild type," Nature, vol. 366, no. 6454, pp. 461-464, 1993.

[84] M. Holzenberger, J. Dupont, B. Ducos et al., "IGF-1 receptor regulates lifespan and resistance to oxidative stress in mice," Nature, vol. 421, no. 6919, pp. 182-187, 2003.

[85] J. Nakae, W. H. Biggs 3rd, T. Kitamura et al., "Regulation of insulin action and pancreatic $\beta$-cell function by mutated alleles of the gene encoding forkhead transcription factor Foxo1," Nature Genetics, vol. 32, no. 2, pp. 245-253, 2002.

[86] J. Z. Morris, H. A. Tissenbaum, and G. Ruvkun, "A phosphatidylinositol-3-OH kinase family member regulating longevity and diapause in Caenorhabditis elegans," Nature, vol. 382, no. 6591, pp. 536-539, 1996.

[87] K. D. Kimura, H. A. Tissenbaum, Y. Liu, and G. Ruvkun, "daf-2, an insulin receptor-like gene that regulates longevity and diapause in Caenorhabditis elegans," Science, vol. 277, no. 5328, pp. 942-946, 1997.

[88] J. B. Dorman, B. Albinder, T. Shroyer, and C. Kenyon, "The age-1 and daf- 2 genes function in a common pathway to control the lifespan of Caenorhabditis elegans," Genetics, vol. 141, no. 4, pp. 1399-1406, 1995.

[89] S. Paradis, M. Ailion, A. Toker, J. H. Thomas, and G. Ruvkun, "A PDK1 homolog is necessary and sufficient to transduce AGE-1 PI3 kinase signals that regulate diapause in Caenorhabditis elegans," Genes \& Development, vol. 13, no. 11, pp. 1438-1452, 1999.

[90] E. B. Gil, E. Malone Link, L. X. Liu, C. D. Johnson, and J. A. Lees, "Regulation of the insulin-like developmental pathway of Caenorhabditis elegans by a homolog of the PTEN tumor suppressor gene," Proceedings of the National Academy of Sciences, vol. 96, no. 6, pp. 2925-2930, 1999.

[91] S. Ogg and G. Ruvkun, "The C. elegans PTEN homolog, DAF-18, acts in the insulin receptor-like metabolic signaling pathway," Molecular Cell, vol. 2, no. 6, pp. 887-893, 1998.

[92] V. T. Mihaylova, C. Z. Borland, L. Manjarrez, M. J. Stern, and H. Sun, "The PTEN tumor suppressor homolog in Caenorhabditis elegans regulates longevity and dauer formation in an insulin receptor-like signaling pathway," Proceedings of the National Academy of Sciences, vol. 96, no. 13, pp. 7427-7432, 1999.
[93] S. S. Lee, S. Kennedy, A. C. Tolonen, and G. Ruvkun, "DAF16 target genes that control C. elegans life-span and metabolism," Science, vol. 300, no. 5619, pp. 644-647, 2003.

[94] C. T. Murphy, S. A. McCarroll, C. I. Bargmann et al., "Genes that act downstream of DAF-16 to influence the lifespan of Caenorhabditis elegans," Nature, vol. 424, no. 6946, pp. 277-283, 2003.

[95] B. J. North and E. Verdin, "Sirtuins: sir2-related NAD-dependent protein deacetylases," Genome Biology, vol. 5, no. 5, p. 224, 2004.

[96] D. Toiber, C. Sebastian, and R. Mostoslavsky, "Characterization of nuclear sirtuins: molecular mechanisms and physiological relevance," Histone Deacetylases: The Biology and Clinical Implication, vol. 206, pp. 189-224, 2011.

[97] T. Sasaki, B. Maier, A. Bartke, and H. Scrable, "Progressive loss of SIRT1 with cell cycle withdrawal," Aging Cell, vol. 5, no. 5, pp. 413-422, 2006.

[98] T. Anwar, S. Khosla, and G. Ramakrishna, "Increased expression of SIRT2 is a novel marker of cellular senescence and is dependent on wild type p53 status," Cell Cycle, vol. 15, no. 14, pp. 1883-1897, 2016.

[99] S. Yamashita, K. Ogawa, T. Ikei, M. Udono, T. Fujiki, and Y. Katakura, "SIRT1 prevents replicative senescence of normal human umbilical cord fibroblast through potentiating the transcription of human telomerase reverse transcriptase gene," Biochemical and Biophysical Research Communications, vol. 417, no. 1, pp. 630-634, 2012.

[100] J. Jeong, K. Juhn, H. Lee et al., "SIRT1 promotes DNA repair activity and deacetylation of Ku70," Experimental \& Molecular Medicine, vol. 39, no. 1, pp. 8-13, 2007.

[101] Z. Yuan and E. Seto, "A functional link between SIRT1 deacetylase and NBS1 in DNA damage response," Cell Cycle, vol. 6, no. 23, pp. 2869-2871, 2007.

[102] P. Oberdoerffer, S. Michan, M. McVay et al., "SIRT1 redistribution on chromatin promotes genomic stability but alters gene expression during aging," Cell, vol. 135, no. 5, pp. 907-918, 2008.

[103] T. L. A. Kawahara, E. Michishita, A. S. Adler et al., "SIRT6 links histone $\mathrm{H} 3$ lysine 9 deacetylation to NF- $\kappa \mathrm{B}$-Dependent gene expression and organismal life span," Cell, vol. 136, no. 1, pp. 62-74, 2009.

[104] Z. Xu, L. Zhang, X. Fei, X. Yi, W. Li, and Q. Wang, "The miR29b-Sirt1 axis regulates self-renewal of mouse embryonic stem cells in response to reactive oxygen species," Cellular Signalling, vol. 26, no. 7, pp. 1500-1505, 2014.

[105] M. Kaeberlein, M. McVey, and L. Guarente, "The SIR2/3/4 complex and SIR2 alone promote longevity in Saccharomyces cerevisiae by two different mechanisms," Genes \& Development, vol. 13, no. 19, pp. 2570-2580, 1999.

[106] B. Rogina and S. L. Helfand, "Sir2 mediates longevity in the fly through a pathway related to calorie restriction," Proceedings of the National Academy of Sciences, vol. 101, no. 45, pp. 15998-16003, 2004.

[107] H. A. Tissenbaum and L. Guarente, "Increased dosage of a sir-2 gene extends lifespan in Caenorhabditis elegans," $\mathrm{Na}$ ture, vol. 410, no. 6825, pp. 227-230, 2001.

[108] Y. Kanfi, S. Naiman, G. Amir et al., "The sirtuin SIRT6 regulates lifespan in male mice," Nature, vol. 483, no. 7388, pp. 218-221, 2012.

[109] A. Berdichevsky, M. Viswanathan, H. R. Horvitz, and L. Guarente, "C. elegans SIR-2.1 interacts with 14-3-3 proteins to activate DAF-16 and extend life span," Cell, vol. 125, no. 6, pp. 1165-1177, 2006. 
[110] Y. Wang and H. A. Tissenbaum, "Overlapping and distinct functions for a Caenorhabditis elegans SIR2 and DAF-16/ FOXO," Mechanisms of Ageing and Development, vol. 127, no. 1, pp. 48-56, 2006.

[111] R. Curtis, G. O'Connor, and P. S. DiStefano, “Aging networks inCaenorhabditis elegans: AMP-activated protein kinase (aak-2) links multiple aging and metabolism pathways," Aging Cell, vol. 5, no. 2, pp. 119-126, 2006.

[112] Y. Sun, X. Hu, G. Hu, C. Xu, and H. Jiang, "Curcumin attenuates hydrogen peroxide-induced premature senescence via the activation of SIRT1 in human umbilical vein endothelial cells," Biological \& Pharmaceutical Bulletin, vol. 38, no. 8, pp. 1134-1141, 2015.

[113] Z. Song, Y. Liu, B. Hao et al., "Ginsenoside Rb1 prevents $\mathrm{H} 2 \mathrm{O} 2$-induced HUVEC senescence by stimulating sirtuin-1 pathway," PLoS One, vol. 9, no. 11, Article ID e112699, 2014. 